\title{
Relationship Between Work Stress, Age, Length of Working, and Subjective Fatigue Among Workers in Production Department of Textiles Factory
}

\author{
Gurdani Yogisutanti ${ }^{1^{*}}$, Heryzal Aditya ${ }^{2}$, Rosmariana Sihombing ${ }^{2}$, Suhat $^{2}$ \\ ${ }^{1}$ Immanuel School of Health Sciences, Jl. Kopo 161, 40234, Bandung, Indonesia \\ ${ }^{2}$ Jenderal Achmad Yani School of Health Sciences, Jl, Terusan Jenderal Sudirman, 40211, Cimahi, Indonesia \\ *Corresponding author. Email: gurdani@yahoo.com
}

\begin{abstract}
Background: Fatigue is one of the risks of a decrease in the health status of the workforce. The risks that can be caused due to fatigue include a decrease in work motivation, low performance, low quality of work, many errors in work, low work productivity, causing work stress. Stress is a situation of emotional tension and pressure experienced by someone when facing many demands and obstacles that can affect one's emotions, thoughts and physical condition. Objective: The purpose of this study was to determine the relationship of work stress, age and years of work with subjective fatigue in the production department employees at PT. Sunrise Bumi Textiles, Bekasi City. Method: This study uses an analytical method with Cross sectional design. The number of samples is 57 people at the time of the entire shift. The sampling technique uses Proportional Random Sampling and Chi Square Test as statistical tests. This study used the IFRC (Industrial Fatigue Research Committee) questionnaire and DASS 21 (Depression Anxiety and Stress Scale). Result: The results of the study revealed that there was a significant relationship between work stress and subjective fatigue $\mathrm{p}$ value $=0.0001$. There is no relationship between age and subjective fatigue $\mathrm{p}$ value $=0.15$, and there is no significant relationship between tenure and subjective fatigue $p$ value $=0.263$. Conclusion: Workers who suffered from work stress more easily become fatigue. Recommendation from this research is: conduct worker placement according to age and years of service, provide a control room to rest, provide drinking water at work, conduct training or training for new workers.
\end{abstract}

Keywords: subjective fatigue, work stress, production department

\section{INTRODUCTION}

Increasingly advanced technological developments cause competition within the company, to be able to produce for 24 hours to achieve maximum profit. Work stress is known as one of psychosocial work factors affect risk of occupational injury among workers ${ }^{1}$. On the jobsite, these workers often confront psychosocial work factors that may increase their risk of injury or poor health outcomes, job insecurity ${ }^{2}$. Fatigue is a problem that is often found in labour. It is an important problem that needs to be dealt properly, because it can cause various problems such as loss of efficiency at work, decreased productivity and work capacity as well as health and survival skills that cause workplace accidents ${ }^{3}$.

Factors causing fatigue in the industry vary greatly, and the work environment can affect worker performance, for example noise, hot work climate, poor lighting and vibration can cause discomfort in working, if working with uncomfortable conditions over time will cause fatigue . $^{4}$

Workload that is too heavy such as getting a night shift will cause a work fatigue that has a negative impact on one's performance. An employee who is experiencing work fatigue will experience a decreased ability to carry out activities. The employee will feel heavy sleepiness, headaches, weak body due to decreased appetite. In addition, employees will also have difficulty thinking, difficulty concentrating, not diligent in working, and lack of confidence. The employee will experience depression and lose initiative. This fatigue is also called clinical fatigue. Work fatigue is a variety of circumstances accompanied by a decrease in efficiency and endurance at work ${ }^{3}$. Fatigue is a variety of circumstances accompanied by decreased endurance at work. Work fatigue also has several risks to workers, namely decreased work motivation, low performance, low quality of work, a lot of mistakes occur, low work productivity, work stress, work-related illness, injury, work accident ${ }^{5}$. Fatigue is a common phenomenon that occurs in various types of work, and each type of work has its own characteristics of fatigue ${ }^{6}$.

Risks that can be caused by fatigue include a decrease in work motivation, low performance, low quality of work, many errors in work, low work productivity, causing work stress. Stress is a common phenomenon in the workplace today. Stress at work can be related to individual task demands, individual role demands, group demands and and 


\section{RESULTS AND DISCUSSION}

tension and stress experienced by a person when facing many demands and obstacles that can affect one's emotions, thoughts and physical condition. People who experience stress become nervous, and feel chronic worries, so they become angry, aggressive, unable to relax, or show an uncooperative attitude ${ }^{8}$.

There is a relationship between work stress felt by workers with work fatigue in the night shift operator PT. Indonesia Bulk Terminal Kotabaru, South Kalimantan, there was a relation between work stress and work fatigue. These are the signsof fatigue and exhaustion that continues lead to work stress ${ }^{9}$.

Based on preliminary research as a result of a preliminary study conducted by the author on Thursday, April 11, 2019 of 20 (twenty) employees in the industrial section of the Ring Frame department of PT. Sunrise Bumi Textiles Bekasi City shows work activities that complain of work stress and cause fatigue such as age, type of work, marital status, and years of service of employees. However, the research that will be discussed by researchers only makes the dimensions of age and years of work as variables related to work stress and work fatigue because of the problem of age and years of work to do with work stress and work fatigue is a very important issue to consider. Based on it, the researchers took a study entitled the relationship between work stress, age and years of work with subjective fatigue in the production department ring frame PT. Sunrise Bumi Textiles Bekasi City in 2019.

\section{METHOD}

This research uses quantitative methods with cross sectional research design. In this study, samples were all workers in casting and forging division. the population in this study were all shift 1 , shift 2 and shift 3 workers in the production section of PT. Sunrise Bumi Textiles Bekasi City, totaling 129 people, and sample used in this study was 57 respondents. Data collection techniques were collected by the researcher himself or directly from the object under study using a questionnaire. Data collected were data on work fatigue and work stress, distributing questionnaires to workers after finishing work at $14.00-15.00 \mathrm{pm}$.

In this study the dependent variable is subjective fatigue and the independent variables are work stress, age and length of work. The research instrument used was the subjective fatigue questionnaire Industrial Fatigue Research Committee (IFRC) to measure work fatigue and Depression Anxiety And Stress Scale (DASS 21) to measure work stress. Bivariate analysis is performed to see the relationship between the independent variable and the dependent variable. To find the relationship between work stress and subjective fatigue using the Chi Square statistical test. This study has received research ethics approval number 002 / EC / STIKI / B / VIII / 2019 from the Health Research Ethics Committee of Immanuel College of Health Bandung.

\section{Result}

This research uses quantitative methods with cross sectional research design. In this study, samples were all workers in casting and forging division. the population in this study were all shift 1 , shift 2 and shift 3 workers in the production section of PT. Sunrise Bumi Textiles Bekasi City, totaling 129 people, and sample used in this study was 57 respondents. Data collection techniques were collected by the researcher himself or directly from the object under study using a questionnaire. Data collected were data on work fatigue and work stress, distributing questionnaires to workers after finishing work at 14.00-15.00 pm.

In this study the dependent variable is subjective fatigue and the independent variables are work stress, age and length of work. The research instrument used was the subjective fatigue questionnaire Industrial Fatigue Research Committee (IFRC) to measure work fatigue and Depression Anxiety And Stress Scale (DASS 21) to measure work stress. Bivariate analysis is performed to see the relationship between the independent variable and the dependent variable. To find the relationship between work stress and subjective fatigue using the Chi Square statistical test. This study has received research ethics approval number $002 /$ EC / STIKI / B / VIII / 2019 from the Health Research Ethics Committee of Immanuel College of Health Bandung.

Table 1 Age, Length of work, work stress and subjective fatigue

\begin{tabular}{lcc}
\hline \multicolumn{1}{c}{ Variables } & f & \% \\
\hline Age & & \\
Not at risk & 26 & 45.6 \\
At risk & 31 & 54.4 \\
Length of work & & \\
$\quad$ Not at risk & 10 & 17.5 \\
$\quad$ At risk & 47 & 82.5 \\
Subjective Fatigue & & \\
$\quad$ Not at risk & 42 & 26.3 \\
At risk & 15 & 73.3 \\
Work Stress & & \\
$\quad$ Not at risk & 48 & 15.8 \\
At risk & 9 & 84.2 \\
\hline
\end{tabular}

Table 2. Assosiation between age, length of work, work stress and subjective fatigue

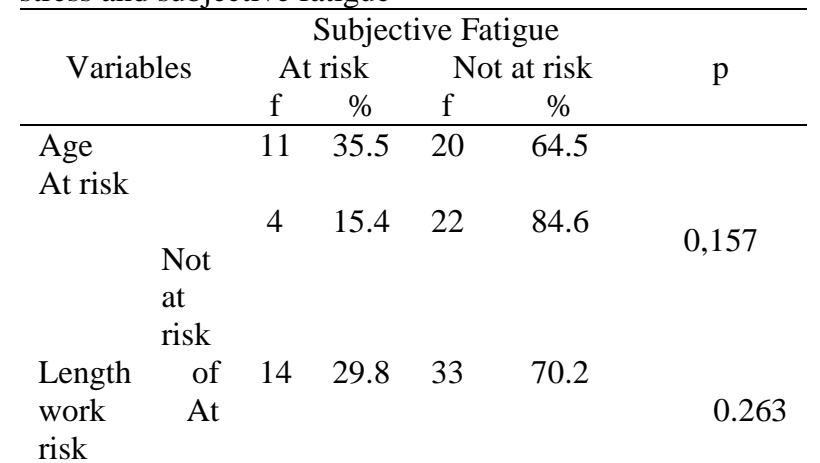




\begin{tabular}{|c|c|c|c|c|c|c|}
\hline & & & ubjec & ve I & gue & \\
\hline Varia & bles & & isk & & at risk & $\mathrm{p}$ \\
\hline & & f & $\%$ & f & $\%$ & \\
\hline & & 1 & 10.0 & 9 & 90.0 & \\
\hline & $\begin{array}{l}\text { Not } \\
\text { at } \\
\text { risk }\end{array}$ & & & & & \\
\hline Work & Stress & 8 & 88,9 & 1 & 11,1 & \\
\hline & $\begin{array}{l}\text { Not } \\
\text { at } \\
\text { risk }\end{array}$ & 7 & 14.6 & 41 & 85,4 & 0.0001 \\
\hline
\end{tabular}

\section{Discussion}

Based on the results of the measurement of work fatigue by filling out the IFRC (Industrial Fatigue Research Committee) questionnaire, it was found that a total of 57 workers in the production section of PT. Sunrise Bumi Textiles Bekasi City in 2019, respondents who experienced high fatigue were $(26.3 \%)$. Respondents who experienced moderate fatigue were $(15.8 \%)$, and respondents who experienced low fatigue were $(57.9 \%)$. Among other types of monotonous work, w" zork climate and hot workspace weather, and pressure from companies that require workers to achieve production targets. Measuring work fatigue is done simultaneously at one time in each work shift. Symptoms that cause subjective fatigue such as feeling heavy on the head, being tired all over the body, legs feeling heavy, yawning, feeling chaotic thoughts, being sleepy, feeling the burden of death, stiff and awkward in motion, unable to concentrate, headache, stiffness in the shoulder, feeling pain in the back, feeling depressed breathing, thirst, hoarseness, feeling dizzy, feeling unwell sometimes felt by workers.

Fatigue is a common phenomenon that occurs in various types of work, and each type of work has its own characteristics of work fatigue. Risks that can be caused by fatigue include a decrease in work motivation, low performance, low quality of work, a lot of mistakes in working, low productivity of work, causing work stress. Stress is a common phenomenon in the workplace today. Stress at work can be related to individual task demands, individual role demands, group demands and organizational demands ${ }^{10}$.

Fatigue can lead to several conditions, namely decreased work performance, the body feels uneasy in addition to decreased work enthusiasm. Work fatigue tends to increase the occurrence of work accidents, so that it can harm the workers themselves and their companies because of a decrease in work productivity ${ }^{11}$.

Testing the relationship of work stress and subjective fatigue using the Chi Square test, the research presented in the Table shows that respondents who experienced subjective fatigue and experienced work stress were $88.9 \%$, and respondents who did not experience subjective fatigue but felt work stress were $11.1 \%$. Respondents who experienced subjective fatigue but did not experience work stress were $14.6 \%$, and respondents who did not experience subjective fatigue and did not experience work stress were $85.4 \%$. Variable subjective fatigue and work stress are measured based on statistical tests obtained $\mathrm{p}$ value $=$ 0.0001 ( $\mathrm{p}$ value $<0.05$ ) meaning that there is a significant relationship between work stress and subjective fatigue in the Production section of PT. Sunrise Bumi Textiles Bekasi City 2019.

Work stress measurement results using the DASS 21 questionnaire (Depression Anxiety Stress Scales) obtained respondents who experienced heavy work stress as much (1.8\%), respondents who experienced moderate work stress as much (14.0\%), respondents who experienced mild work stress as much (12.3\%), and respondents who did not experience work stress or normal work stress (71.9\%). Feelings of boredom due to monotonous work, the same work that is done repeatedly from day to day without any variation can cause boredom, bored, stressed and tired quickly are images of stress felt by workers in the production section of PT. Sunrise Bumi Textiles Bekasi City in 2019.

From 57 respondents in the Production Section of PT. Sunrise Bumi Textiles Bekasi City in 2019 workers aged $\geq 35$ years amounted to 31 people or as many as $54.4 \%$ and workers aged $\leq 35$ years totaled 26 people or as many as $45.6 \%$. Age is one of the factors that affect an individual's work ability. The hourly energy consumption on the condition of working muscles for each person is different, one of which is the age factor. Someone's age factor will affect the basal metabolism will decrease and the individual will easily experience fatigue ${ }^{3}$.

Work period is the length of time an employee contributes his strength to a particular company where the workforce can achieve satisfactory results in work depending on the ability, skills and certain skills in order to carry out the work properly. Long working period will tend to make an employee feel more comfortable in a company, this is due to the fact that they have adapted to their environment long enough so that an employee will feel comfortable with their workers ${ }^{12}$.

Factors that affect fatigue there are two internal factors and external factors. Internal factors which include, factors somatic or physical factors, nutrition, sex, age, knowledge and attitude or lifestyle. While including external factors is the physical state of the working environment (noise, temperature, lighting, chemical factors (toxic substances), biological factors (bacteria, fungi), ergonomic factors, job categories, nature of work, discipline or company regulations, wages, social relations and working position ${ }^{9}$

The amount of stress experienced by a person depends on various factors. Heredity plays a role in determining the type of autonomic response and which organ systems will be affected. Other factors are related to lifestyle-such as sleeping and eating habits and behavioral type. The reaction to stress will depend on what strategies are available to the individual-such as relaxation techniques and finding a balance. Work style, organizational skills, attitude towards unpredictable and difficult situations, trust in own abilities, handling of traumatic situations, and "luck" will also determine a person's susceptibility to stress at work ${ }^{13}$. The 
Kelelahan pada Karyawan Bagian Produksi PT Arwana Anugrah Keramik Tbk. Jurnal Ilmu Kesehatan Masyarakat, 53-63.

[5] Suma'mur. (2009). Higiene Perusahaan dan Kesehatan Kerja (HIPERKES). Jakarta: Sagung Seto.

[6] Yogisutanti, G., Kusnanto, H., Setyawati, L., \& Otsuka, Y. (2013). Kebiasaan Makan Pagi, Lama Tidur dan Kelelahan Kerja (Fatigue) pada Dosen. KEMAS, 5357.

[7] Borkowski. (2015). Manajemen Pelayanan Kesehatan Perilaku Organisasi. Jakarta: EGC.

[8] Hasibuan, M. (2012). Manajemen Sumber Daya Manusia. Jakarta: PT Bumi Aksara.

[9] Sholihah, Q., \& Fauziah, R. (2013). Relationship Work Fatigue Relate to Work Stress on Circardian Rhythm Night Shift Operator Employee PT Indonesia Bulk Terminal Kota Baru, South Kalimantan, Indonesia. The European Journal of Social Behaviaoral Science, 1423-1430.

[10] Widyastuti, D. (2017). Hubungan stres kerja dngan kelelahan kerja pada pekerja area workshop kontruki Box Truck. Surabaya: FKM Universitas Airlangga.

[11] Setyawati, L. (2010). Selintas tentang Kelelahan Kerja, Manajemen Kelelahan Kerja dan Jawabannya. Yogyakarta: Amara Books.

[12] Nadialis, E. C., \& Nugrohoseno, D. (2014). Hubungan Usia, Masa Kerja dan Beban Kerja dengan Stress Kerja. Jurnal Ilmu Manajemen, Vol 2 (2):489-501.

[13] Onciul, J. V. (1996). Stress at Work. BNJ, Vol 313 (21): 745-748.

[14] Palar, J. F., Kawatu, P. A., \& Rumayar, A. A. (2015). Hubungan antara stres kerja dan kelelahan kerja dengan produktivitas kerja pada pekerja PT. TImurjaya Dayatama Sonder. Jurnal Administrasi Publik , 4 (32). [1] Clouser, J. M., Bush, A., Gan, W., \& Swanberg, J.
(2018). Association of Work Stress, Supervisor Unfairness, and Supervisor Inability to Speak Spanish with Occupationall Injury among Latino Farmworkers. Journal Immigrant Minority Health, 20 (894-901), 894901.

[2] Landsbergis, PA; Grzywacz, JG; LaMontagne, AD. (2014). Work organizatioan, job insecutiry, and occupational health disparities. Am J Ind Mes , 57, 495515.

[3] Tarwaka. (2015). Ergonomi Industri. Surakarta: Harapan Press.

[4] Juliana, M. (2018). Analisis Faktor Risiko 